\title{
ANALISIS KESALAHAN BERBAHASA DI BIDANG DIKSI DALAM BUKU PANDUAN UPT PERPUSTAKAAN IAIN SURAKARTA EDISI 2018
}

\author{
Nurul Fajriyani ${ }^{1}$, M. Rosyid Ridho ${ }^{2}$, dan Qori'atul Laili ${ }^{3}$ \\ Institut Agama Islam Negeri Surakarta \\ Jalan Pandawa, Pucangan, Kartasura, Sukoharjo, Indonesia
}

Email: nurulfajriyani593@gmail.com; rosyid.ridho022@gmail.com; qoriatullailiya@gmail.com

Phone:+6283145644453

Submitted: 2019-08-05

Accepted: 2020-01-30

Published: 2020-02-01

\begin{tabular}{ll}
\hline Keywords: & Abstract \\
\hline Error Analysis, & The library guide book certainly has a significant role in the \\
Diction, Spelling, & learning process for new students. All forms of direction contained \\
Manuals & in this book are important to consider in terms of language. This \\
study aimed to describe language errors in diction and spelling \\
found in the guide book. The purpose of this study was to describe \\
language errors in the diction and spelling. The research method \\
used was descriptive qualitative, using error analysis framework. \\
Data collection technique was done qualitatively. The data \\
analysis was done in the following stages: processing and \\
preparing data to be analyzed, reading and describing the entire \\
data, recording all data obtained, analyzing more details and \\
describing errors in each data, classifying each data in spelling or \\
diction fields, and interpreting all data according to relevant. The \\
results of the analysis indicated that there were 25 errors on \\
diction, consisting of 3 prepositional writing errors, 17 standard \\
word writing errors, and 5 italics writing data. In addition, there \\
were 10 errors the spelling field, consisting of 2 data on \\
punctuation, and 8 errors in the use offoreign words.
\end{tabular}

\section{Kata Kunci:}

Analisis Kesalahan,

Diksi, Ejaan, Manual

\section{Abstrak}

Buku panduan perpustakaan tentunya memiliki peran penting dalam proses pembelajaran bagi siswa baru. Semua bentuk arahan yang terkandung dalam buku ini penting untuk dipertimbangkan dalam hal bahasa. Penelitian ini bertujuan untuk mendeskripsikan kesalahan bahasa dalam diksi dan ejaan yang ditemukan dalam buku panduan. Tujuan penelitian ini adalah mendeskripsikan kesalahan berbahasa bidang diksi dan ejaan. Metode penelitian yang digunakan adalah deskriptif kualitatif, menggunakan kerangka analisis kesalahan. Teknik pengumpulan data dilakukan secara kualitatif. Analisis data dilakukan dalam langkah-langkah berikut: mengolah dan menyiapkan data untuk dianalisis, membaca dan mendeskripsikan seluruh data, mencatat semua data yang diperoleh, menganalisis lebih detail dan menjelaskan kesalahan dalam setiap data, mengklasifikasikan setiap data dalam bidang ejaan atau diksi, dan menafsirkan semua data yang relevan. Hasil analisis menunjukkan bahwa ada 25 
kesalahan pada diksi, yang terdiri atas 3 kesalahan penulisan preposisi, 17 kesalahan penulisan kata standar, dan 5 data penulisan miring. Selain itu, ada 10 kesalahan bidang ejaan, terdiri atas 2 data pada tanda baca, dan 8 kesalahan dalam penggunaan istilah-istilah asing.

\section{PENDAHULUAN}

Bahasa adalah salah satu alat komunikasi yang berfungsi untuk menangkap maksud pesan yang dituturkan oleh penutur. Bahasa Indonesia memiliki fungsi sebagai alat komunikasi utama bagi masyarakat Indonesia. Bahasa Indonesia pada umumnya memiliki keterampilan yang harus dikuasai yakni keterampilan membaca, menyimak, berbicara dan menulis. Empat keterampilan tersebut dikuasai oleh ahli bahasa, sedangkan beberapa masyarakat Indonesia masih mengalami kesalahan berbahasa. Lain halnya dengan orang yang memiliki keahlian di luar bidang kebahasaan, banyak kesalahan berbahasa yang dialami terutama keterampilan menulis.

Kesalahan berbahasa adalah suatu penggunan bahasa yang tidak sesuai dengan kaidah bahasa Indonesia, baik lisan atau tulis, sedangkan analisis kesalahan berbahasa adalah suatu kegiatan yang mengkritik, memperbaiki, dan mengumpulkan suatu data kesalahan berbahasa dan mengklasifikasikannya sesuai bidangnya. Analisis kesalahan berbahasa memiliki orientasi yang dilihat bidang lingustik, yang berkaitan dengan semantik, morfologi, leksikal, dan fonologi.

Kesalahan berbahasa merupakan suatu kejadian yang berhubungan erat pada setiap pemakaian bahasa, baik lisan maupun tulis (Supriani \& Siregar, 2012). Bahasa digunakan sebagai alat komunikasi dalam keseharian. Kesalahan berbahasa adalah pemakaian bahasa yang menyimpang pada aturan kaidah kebahasaan yang berlaku (Nurwicaksono \& Amelia, 2014). Kesalahan berbahasa merupakan sebuah kesalahan berbahasa yang meyimpang dari kaidah bahasa baik lisan maupun tulis (Johan, 2018). Dapat disimpulkan bahwa kesalahan berbahasa adalah penyimpangan bahasa baik secara lisan ataupun tulisan yang tidak sesuai dengan kaidah ketataaturan kebahasaan yang berlaku.

Dalam artikel dibahas lebih dalam mengenai kesalahan berbahasa dalam bentuk tulisan pada bagian diksi. Diksi merupakan sebuah bahasa yang digunakan oleh seseorang dalam kemampuannya berkomunikasi atau berbahasa dalam mendayagunakan kata yang tepat dan sesuai (Hidayatullah, 2018). Menurut Hidayah kesalahan diksi masuk dalam kategori kata tidak baku, gramatikal, makna, dan perubahan kata yang memiliki kesalahan berbeda pada masing-masing bidang. Penggunaan kata tidak baku merupakan sebuah kesalahan yang terjadi karena tidak sesuai dengan kaidah bahasa (Hidayatullah, 2018). Tidak lain halnya menurut Widjono Hs (2007: 98), diksi merupakan kesesuaian penggunaan kata yang dipilih.

Diksi dapat dimaknai sebagai bagian dari pengambilan kata oleh seorang penulis yang bertujuan untuk menyusun kalimat yang tepat. tidak jauh berbeda dengan pandangan (Sumartono, 2014) bahwa diksi merupakan suatu kata yang digunakan untuk menyatakan perasaan atau pikiran yang dijelaskan dalam pola kalimat dengan tepat.

Ejaan adalah semua aturan yang melambangkan bunyi suatu ujaran, penempatan tanda baca, penggabungan dan pemisahan suatu kata (Hadijah, 2018). Ejaan juga diartikan sebagai kaidah atau cara yang melambangkan bunyi suatu tuturan serta yang melambangkan pemisahan dan penggabungan suatu bahasa. Sama halnya dengan pendapat (Efrilla, Sari, \& Rahmi, 2017), ejaan ditinjau dari umum dan khusus dan berartikan bahwa ketentuan yang mengatur mengenai lambang suatu bunyi, penggabungannya, serta penggunaan tanda baca. Dari beberapa pendapat di atas bahwa 
ejaan merupakan suatu kaidah yang berisikan mengenai lambing suatu tuturan, ujaran serta pemisahan dan penggabungan suatu kata dalam kalimat.

Keterampilan menulis belum banyak dikuasai oleh masyarakat Indonesia pada umumnya, namun bisa dikuasai dengan cara meningkatkan intensitas kegiatan menulis dan membaca. Kesalahan pada tulisan sering terdapat pada pengambilan diksi yang kurang tepat pada pedoman umum ejaan bahasa Indonesia (PUEBI). Oleh karena itu, artikel ini fokus pada pengambilan atau penempatan diksi yang sering kali kurang tepat. Kesalahan peenggunaan diksi dalam setiap kalimat banyak ditemui pada penulisan buku secara tidak sengaja atau karena ketidaktahuan dari penulis. Seperti yang terdapat dalam buku panduan perpustakaan IAIN Surakarta. Buku panduan bisa disebut juga buku petunjuk, yaitu memuat tata cara mengenai suatu hal dalam melakukan sesuatu pekerjaan atau aktivitas tertentu. Buku panduan merupakan sebuat buku yang berisi tentang ketentuan-ketentuan dalam menjalankan perintah suatu kegiatan.

Objek utama sebagai data yang dipakai dalam penelitian analisis kesalahan berbahasa ini adalah buku panduan perpustakaan yang dibuat oleh institusi perpustakaan IAIN Surakarta. Salah satu halangan dalam proses komunikasi yaitu kurangnya kecakapan berbahasa. Bentuk kurangnya kecakapan berbahasa yaitu dikarenakan kesalahan berbahasa. Gangguan komunikasi disebabkan karena kesalahan berbahasa, terkecuali kesalahan berbahasa yang digunakan secara khusus seperti humor, puisi dan bahasa iklan. Penggunaan bahasa yang khusus tersebut sengaja digunakan dan disadari oleh penutur untuk mendapatkan efek tertentu, seperti halnya menarik perhatian, menginspirasi, dan membuat tertawa.

Buku panduan perpustakaan IAIN Surakarta merupakan salah satu sarana pengenalan perpustakaan kepada mahasiswa baru IAIN Surakarta. Pengenalan seputar perpustakaan terhadap mahasiswa baru perlu dilakukan mengingat pentingnya perpustakan sebagai sarana bagi mahasiswa untuk mencari buku referensi dalam perkuliahannya. Pengenalan itu meliputi profil, fasilitas, koleksi, prosedur pelayanan, peraturan, hingga denah perpustakan IAIN Surakarta. Buku panduan tersebut, apabila dilihat dari segi isinya, penting untuk memperhatikan kaidah penulisan yang baik dan benar. Karena buku tersebut tergolong buku nonfiksi, maka dari segi kaidah kebahasaan perlu diperhatikan secara saksama.

Selain itu, apabila bahasa yang digunakan sudah sesuai dengan kaidah, dapat dijadikan rujukan bagi pembaca agar tidak menimbulkan kesalahan tafsir dan kesalahan berbahasa lainnya. Namun dalam praktiknya, masih ditemukan beberapa kesalahan kaidah kebahasaan dalam buku panduan perpustakaan IAIN Surakarta. Sebagaimana buku pengetahuan lainnya, fungsi buku panduan perpustakan sebagai rujukan informasi bagi mahasiswa seharusnya memiliki kriteria yang baik bukan hanya dari segi konten yang terdapat di dalamnya melainkan juga cara (bahasa) penyampaiannya. Oleh karena itu, adanya kesalahan-kesalahan tersebut layak untuk dinanalisis agar ke depannya kesalahan serupa tidak terulang.

Searah dengan latar belakang di atas, maka dirumuskan permasalahan bahwa terdapat kesalahan penggunaan atau penempatan diksi di dalam susunan kalimat pada buku panduan perpustakaan IAIN Surakarta, maka perlu ditindaklanjuti dengan memperbaiki dan menganalisis kesalahan tersebut. Hal itu digunakan dalam upaya untuk memperbaiki kesalahan berbahasa dan pengajarannya. Penelitian relevan yang mengkaji ejaan beserta diksi yakni penelitian yang dilakukan oleh Efrilla (2017) dengan judul "Analisis Kesalahan Penggunaan Ejaan dan Diksi dalam Berita Surat Kabar Posmetro Padang." Hasil analisis penelitian tersebut memperlihatkan kesalahan ejaan yaitu berupa kesalahan penggunaan huruf kapital, penggunaan kata depan dan partikel, penggunaan huruf kapital, dan pemakaian tanda baca, sedangkan kesalahan diksi yaitu 
membedakan kata yang hampir bersinonim yang kurang tepat. Penelitian tersebut memiliki perbedaan terhadap objek yang dikaji bersifat literatur yaitu, sedangkan persamaannya yaitu terdapat pada kajian kesalahan ejaan dan diksi.

Penelitian kedua yang relevan dilakukan oleh Hadijah (2018) dengan judul "Analisis Kesalahan Ejaan dan Diksi pada Karangan Teks Deskripsi Siswa Kelas VII/B SMP Negeri 2 Gunungsari." Hasil penelitian tersebut menjelaskan bahwa kesalahan ejaan berupa penulisan penggunaan kata, penggunaan huruf kapital, penggunaan tanda baca, sedangkan kesalahan diksi terdapat pada pilihan kata yang tidak sesuai. Tidak jauh berbeda persamaan penelitian tersebut dengan penelitian relevan pertama, yaitu mengkaji kesalahan ejaan dan diksi. Perbedaannya terdapat pada objek kajian di lapangan yaitu karangan teks deskripsi siswa kelas VII/B SMP Negeri 2 Gunungsari.

\section{METODE PENELITIAN}

Jenis penelitian ini termasuk deskriptif kualitatif. Penelitian kualitatif ialah metode penelitian yang dilakukan untuk meneliti sebuah objek dengan pengumpulan sumber data secara purposive (bertujuan), analisis sebuah data ini bersifat induktif kualitatif dan hasil dari penelitian deskriptif ini menunjukkan sebuah deskripsi data analisis (Sugiyono, 2018). Penelitian kualitatif merupakan penelitian yang dilakukan dengan memahami suatu kesalahan yang berada pada sebuah buku atau data utama dan dengan cara mendeskripsikan kata-kata dengan metode alamiah (Moleong, 2014).

Teknik pengumpulan data yang digunakan yaitu baca, catat, dan analisis. Adapun dalam penelitian ini terdapat beberapa kesalahan berbahasa yang di dalamnya terdiri dari kesalahan fonologi, morfologi, sintaksis, dan semantik. Analisis penelitian ini menggunakan langkah analisis yaitu mengolah dan mempersiapkan objek data untuk dianalisis, membaca dan menguraikan keseluruhan data, mencatat semua data yang diperoleh, menganalisis lebih detail dan mendeskripsikan kesalahan setiap data, mengklasifikasikan setiap data dalam bidang ejaan atau diksi, dan menginterpretasi seluruh data sesuai dengan teori yang telah disajikan.

\section{HASIL DAN PEMBAHASAN}

\section{A. Hasil Penelitian}

\section{Hasil Penelitian Kesalahan Diksi}

Hasil penelitian ini menunjukkan adanya kesalahan bebahasa dalam bidang diksi yang terdapat dalam buku panduan perpustakaan UPT Pusat Perpustakaan IAIN Surakarta Tahun 2018/2019 sejumlah 32 data kesalahan kata.

\begin{tabular}{llll}
\hline No & $\begin{array}{c}\text { Kata yang } \\
\text { salah }\end{array}$ & \multicolumn{1}{c}{ Jenis Kesalahan } & \multicolumn{1}{c}{ Jumlah Kesalahan } \\
\hline 1. & Disini & $\begin{array}{l}\text { Kesalahan penulisan } \\
\text { kata depan }\end{array}$ & $\begin{array}{l}\text { Satu kesalahan terdapat di } \\
\text { halaman 17 }\end{array}$ \\
\hline 2. & Disinilah & $\begin{array}{l}\text { Kesalahan penulisan } \\
\text { kata depan }\end{array}$ & $\begin{array}{l}\text { Satu kesalahan terdapat di } \\
\text { halaman 17 }\end{array}$ \\
\hline 3. & Dimana & $\begin{array}{l}\text { Kesalahan penulisan } \\
\text { kata depan }\end{array}$ & $\begin{array}{l}\text { Satu kesalahan terdapat di } \\
\text { halaman 32 }\end{array}$ \\
\hline 4. & Mushola & $\begin{array}{l}\text { Kesalahan penulisan } \\
\text { kata baku }\end{array}$ & $\begin{array}{l}\text { Satu kesalahan terdapat di } \\
\text { halaman 18 }\end{array}$ \\
\hline 5. & Al Qur'an & $\begin{array}{l}\text { Kesalahan penulisan } \\
\text { kata baku }\end{array}$ & $\begin{array}{l}\text { Tiga kesalahan terdapat di } \\
\text { halaman 19 }\end{array}$ \\
\hline 6. & Nomer & Kesalahan penulisan & Satu kesalahan terdapat di \\
\hline
\end{tabular}




\begin{tabular}{|c|c|c|}
\hline & kata baku & halaman 23 \\
\hline 7. Silahkan & $\begin{array}{l}\text { Kesalahan penulisan } \\
\text { kata baku }\end{array}$ & $\begin{array}{l}\text { Dua kesalahan terdapat di } \\
\text { halaman } 27\end{array}$ \\
\hline 8. $\quad$ Mengklik & $\begin{array}{l}\text { Kesalahan penulisan } \\
\text { kata baku }\end{array}$ & $\begin{array}{l}\text { Dua kesalahan terdapat di } \\
\text { halaman } 28 \text { dan } 29\end{array}$ \\
\hline 9. $\quad$ Plagiarism & $\begin{array}{l}\text { Kesalahan penulisan } \\
\text { huruf miring }\end{array}$ & $\begin{array}{l}\text { Satu kesahanan terdapat di } \\
\text { halaman } 35\end{array}$ \\
\hline 10. Diijinkan & $\begin{array}{l}\text { Kesalahan penulisan } \\
\text { kata baku }\end{array}$ & $\begin{array}{l}\text { Satu kesalahan terdapat di } \\
\text { halaman } 39\end{array}$ \\
\hline 11. Desertasi & $\begin{array}{l}\text { Kesalahan penulisan } \\
\text { huruf miring }\end{array}$ & $\begin{array}{l}\text { Satu kesalahan terdapat di } \\
\text { halaman } 39\end{array}$ \\
\hline 12. Mentaati & $\begin{array}{l}\text { Kesalahan penulisan } \\
\text { huruf miring }\end{array}$ & $\begin{array}{l}\text { Satu kesalahan terdapat di } \\
\text { halaman } 44\end{array}$ \\
\hline 13. Seijin & $\begin{array}{l}\text { Kesalahan penulisan } \\
\text { kata baku }\end{array}$ & $\begin{array}{l}\text { Dua kesalahan terdapat di } \\
\text { halaman } 44\end{array}$ \\
\hline 14. Pasca sarjana & $\begin{array}{l}\text { Kesalahan penulisan } \\
\text { huruf miring }\end{array}$ & $\begin{array}{l}\text { Satu kesalahan terdapat di } \\
\text { halaman } 45\end{array}$ \\
\hline 15. Difotocopy & $\begin{array}{l}\text { Kesalahan penulisan } \\
\text { kata baku }\end{array}$ & $\begin{array}{l}\text { Dua kesalahan terdapat di } \\
\text { halaman } 39\end{array}$ \\
\hline 16. Memfotocopy & $\begin{array}{l}\text { Kesalahan penulisan } \\
\text { kata baku }\end{array}$ & $\begin{array}{l}\text { Satu kesalahan terdapat di } \\
\text { halaman } 39\end{array}$ \\
\hline 17. Fotocopy & $\begin{array}{l}\text { Kesalahan penulisan } \\
\text { kata baku }\end{array}$ & $\begin{array}{l}\text { Dua kesalahan terdapat di } \\
\text { halaman } 45\end{array}$ \\
\hline 18. Didownload & $\begin{array}{l}\text { Kesalahan penulisan } \\
\text { kata baku }\end{array}$ & $\begin{array}{l}\text { Satu kesalahan terdapat di } \\
\text { halaman } 28\end{array}$ \\
\hline 19. Locker & $\begin{array}{l}\text { Kesalahan penulisan } \\
\text { huruf miring }\end{array}$ & $\begin{array}{l}\text { Satu kesalahan terdapat di } \\
\text { halaman } 27\end{array}$ \\
\hline 20. $\quad$ Thesis & $\begin{array}{l}\text { Kesalahan penulisan } \\
\text { huruf miring }\end{array}$ & $\begin{array}{l}\text { Tiga kesalahan terdapat di } \\
\text { halaman } 23,24 \text {, dan } 26\end{array}$ \\
\hline 21. TURNITIN & $\begin{array}{l}\text { Kesalahan penulisan } \\
\text { huruf capital }\end{array}$ & $\begin{array}{l}\text { Dua kesalahan terdapat di } \\
\text { halaman } 35\end{array}$ \\
\hline 22. Memriksa & $\begin{array}{l}\text { Kesalahan penulisan } \\
\text { kata baku }\end{array}$ & $\begin{array}{l}\text { Satu kesalahan terdapat di } \\
\text { halaman } 35\end{array}$ \\
\hline Total kesalahan & & $\begin{array}{l}\text { Tiga puluh dua data } \\
\text { kesalahan berbahasa dalam } \\
\text { bidang diksi }\end{array}$ \\
\hline
\end{tabular}

\section{Hasil Penelitian Kesalahan Ejaan}

Hasil penelitian ini menunjukkan adanya kesalahan bebahasa dalam bidang ejaan yang terdapat dalam buku panduan perpustakaan UPT Pusat Perpustakaan IAIN Surakarta Tahun 2018/2019 sejumlah 10 data kesalahan kata.

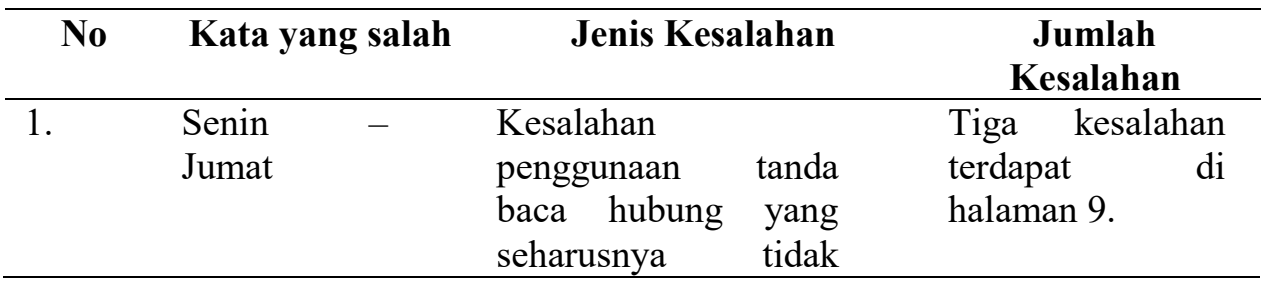




\begin{tabular}{|c|c|c|c|}
\hline & & $\begin{array}{l}\text { terpisah melainkan } \\
\text { tergabung. }\end{array}$ & \\
\hline 2. & Display & $\begin{array}{l}\text { Kesalahan penulisan } \\
\text { kata dari bahasa asing } \\
\text { harus miring. }\end{array}$ & $\begin{array}{l}\text { Satu kesalahan } \\
\text { terdapat di } \\
\text { halaman } 17 .\end{array}$ \\
\hline 3. & Lobby & $\begin{array}{l}\text { Kesalahan penulisan } \\
\text { kata dari bahasa asing } \\
\text { harus miring. }\end{array}$ & $\begin{array}{l}\text { Satu kesalahan } \\
\text { terdapat } \\
\text { halaman } 17 .\end{array}$ \\
\hline 4. & Cybernet & $\begin{array}{l}\text { Kesalahan penulisan } \\
\text { kata dari bahasa asing } \\
\text { harus miring. }\end{array}$ & $\begin{array}{l}\text { Satu kesalahan } \\
\text { terdapat di } \\
\text { halaman } 17 .\end{array}$ \\
\hline 5. & $\begin{array}{l}\text { Di } \\
\text { perpustakaan }\end{array}$ & $\begin{array}{l}\text { Kesalahan penulisan } \\
\text { tanda baca diakhir } \\
\text { kalimat dengan tanda } \\
\text { baca “.". }\end{array}$ & $\begin{array}{l}\text { Satu kesalahan } \\
\text { terdapat } \\
\text { halaman } 17 .\end{array}$ \\
\hline 6. & Copy & $\begin{array}{l}\text { Kesalahan penulisan } \\
\text { kata dari bahasa asing } \\
\text { harus miring. }\end{array}$ & $\begin{array}{l}\text { Satu kesalahan } \\
\text { terdapat di } \\
\text { halaman 19. }\end{array}$ \\
\hline 7. & Dewey & $\begin{array}{l}\text { Kesalahan penulisan } \\
\text { kata dari bahasa asing } \\
\text { harus miring. }\end{array}$ & $\begin{array}{l}\text { Satu kesalahan } \\
\text { terdapat di } \\
\text { halaman } 19 .\end{array}$ \\
\hline 8. & Password & $\begin{array}{l}\text { Kesalahan penulisan } \\
\text { kata dari bahasa asing } \\
\text { harus miring. }\end{array}$ & $\begin{array}{l}\text { Dua kesalahan } \\
\text { terdapat di } \\
\text { halaman } 31 .\end{array}$ \\
\hline 9. & Username & $\begin{array}{l}\text { Kesalahan penulisan } \\
\text { kata dari bahasa asing } \\
\text { harus miring. }\end{array}$ & $\begin{array}{l}\text { Satu kesahanan } \\
\text { terdapat di } \\
\text { halaman } 31 .\end{array}$ \\
\hline 10. & Locker & $\begin{array}{l}\text { Kesalahan penulisan } \\
\text { kata dari bahasa asing } \\
\text { harus miring. }\end{array}$ & $\begin{array}{l}\text { Satu kesalahan } \\
\text { terdapat } \\
\text { halaman } 37 .\end{array}$ \\
\hline \multicolumn{3}{|c|}{ Total kesalahan } & $\begin{array}{l}\text { Sepuluh data } \\
\text { kesalahan } \\
\text { berbahasa } \\
\text { dalamm bidang } \\
\text { ejaan. }\end{array}$ \\
\hline
\end{tabular}

\section{B. Pembahasan}

Data hasil penelitian di atas menunjukkan analisis kesalahan berbahasa tataran diksi dan ejaan dalam buku panduan perpustakaan UPT Perpustakaan Pusat IAIN Surakarta. Data tersebut dapat diuraikan sebagai berikut:

1. Kesalahan Bidang Diksi

a. Kesalahan Penulisan Kata Depan

1) Disinilah

Dalam buku panduan perpustakaan IAIN Surakarta halaman 17 tertulis kalimat sebagai berikut:

Ruang petugas perpustakaan melayani peminjaman dan pengembalian buku oleh pemustaka, disinilah transaksi buku dilakukan dengan sistem automasi perpustakaan. 
Data di atas menunjukkan kesalahan penulisan kata depan di yang seharusnya dipisah dari kata yang mengikutinya karena hal itu merupakan kata penunjuk yang menyatakan tempat. Selanjutnya, kata partikel -lah dihilangkan karena tidak sesuai dengan kaidah penulisan kata baku dalam PUEBI. Penulisan yang tepat yaitu di sini.

2) Disini

Dalam buku panduan perpustakaan IAIN Surakarta halaman 17 tertulis kalimat sebagai berikut:

Ruang Javanese Corner merupakan tempat dan layanan koleksi Javanese, disini tersimpan koleksi berbentuk buku tercetak dan digital manuskrip tentang literatur Jawa yang mencakup bahasa, satra, dan budaya Jawa.

Data di atas menunjukkan kesalahan penulisan kata depan di yang seharusnya dipisah dari kata yang mengikutinya karena hal itu merupakan kata penunjuk yang menyatakan tempat. Hal itu melanggar aturan dalam PUEBI. Penulisan yang tepat yaitu di sini.

3) Dimana

Dalam buku panduan perpustakaan IAIN Surakarta halaman 32 tertulis kalimat sebagai berikut:

ILibry dapat diakses dimana saja, kapan saja, dan oleh siapa saja ada koneksi internet secara online.

Data di atas menunjukkan kesalahan penulisan kata depan $d i$ yang seharusnya dipisah dari kata yang mengikutinya karena hal itu merupakan kata penunjuk yang menyatakan tempat. Hal itu melanggar aturan dalam PUEBI. Penulisan yang tepat yaitu di sini.

b. Kesalahan Penulisan Kata Baku

4) Mushola

Dalam buku panduan perpustakaan IAIN Surakarta halaman 18 tertulis kalimat sebagai berikut:

Mushola

Data di atas menunjukkan kesalahan penulisan kata baku. Hal itu melanggar aturan dalam KBBI. Penulisan yang tepat yaitu Musala.

5) Al Qur'an

Dalam buku panduan perpustakaan IAIN Surakarta halaman 19 tertulis kalimat sebagai berikut:

Al Qur'an dan ilmu yang berkaitan

Data di atas yang bergaris miring menunjukkan kesalahan penulisan kata baku. Hal itu melanggar aturan dalam $K B B I$ V. Penulisan yang tepat yaitu Alquran. 
6) Nomer

Dalam buku panduan perpustakaan IAIN Surakarta halaman 23 tertulis kalimat sebagai berikut:

Keterangan kode nomer

Data di atas yang bergaris miring menunjukkan kesalahan penulisan kata baku. Hal itu melanggar aturan dalam $K B B I V$. Penulisan yang tepat yaitu nomor.

7) Silahkan

Dalam buku panduan perpustakaan IAIN Surakarta halaman 27 tertulis kalimat sebagai berikut:

Dapatkan aplikasi mLibys IAIN Surakarta di Google Play Store, silahkan download....

Berdasarkan data di atas yang bergaris miring, terdapat kesalahan berupa penambahan fonem [h] pada kata silahkan. Hal ini dipengaruhi dialek dan kebiasaan pengucapan pada masyarakat yang menambahkan fonem [h] pada kata silakan menjadi silahkan. Selain itu, data tersebut menunjukkan kesalahan pada penulisan kata baku. Hal itu melanggar aturan dalam $K B B I V$. Penulisan yang benar yaitu silakan, fonem [h] dihilangkan.

8) Silahkan mengklik

Dalam buku panduan perpustakaan IAIN Surakarta halaman 28 dan 29 tertulis kalimat sebagai berikut:

Untuk melihat menu seperti daftar koleksi silahkan mengklik icon pada pojok kiri dan akan muncul tampilan berikut ini....

Kata silahkan dan mengklik pada data tersebut merupakan kesalahan penulisan penggunaan kata baku. Pada kata silahkan terdapat kesalahan berupa penambahan fonem [h]. Penulisan yang benar dan sesuai dengan $K B B I V$ yaitu silakan. Pada data berikutnya yakni pada kata mengklik terjadi kesalahan penulisan morfem [menge-] sehingga hal itu juga menimbulkan kesalahan pada penulisan kata baku. Penulisan yang tepat yaitu mengeklik.

9) TURNITIN, memriksa dan plagiarism

Dalam buku panduan perpustakaan IAIN Surakarta halaman 35 tertulis kalimat sebagai berikut:

Software TURNITIN ini disediakan oleh perpustakaan untuk para dosen guna memperlancar proses belajar mengajar mahasiswa dan dosen termasuk memriksa tulisan mahasiswa dari kemungkinan plagiarism.

Pada data di atas, terdapat tiga kesalahan yaitu pada kata TURNITIN, memriksa dan plagiarism. Pada kata TURNITIN terdapat kesalahan berupa penulisan huruf kapital. memriksa erdapat kesalahan berupa "imbuhan [mem-] pada kata periksa". Periksa berarti melihat dengan teliti (KBBI Daring V). Kata periksa merupakan kata dasar dan diawali huruf $[\mathrm{P}]$ dan meluluhkan fonem [pe-] menjadi [riksa], dan fonem [R] 
diawal kata tidak bisa luluh, sehingga ketambahan fonem [e] pada awalan [meme-]. Pembenarannya yaitu Memeriksa.

10) Dijinkan

Dalam buku panduan perpustakaan IAIN Surakarta halaman 39 tertulis kalimat sebagai berikut:

Pemakai hanya diijinkan menggunakan komputer yang sudah dinyalakan oleh petugas

Kata diijinkan pada kalimat tersebut merupakan bentuk tidak baku. Hal itu termasuk dalam kesalahan penggunaan kata baku karena hal itu melanggar kaidah PUEBI. Penulisan yang tepat yaitu diizinkan.

11) Desertasi

Dalam buku panduan perpustakaan IAIN Surakarta halaman 39 tertulis kalimat sebagai berikut:

Careel room diperuntukkan bagi staf pengajar yang sedang menyusun dan menyelesaikan riset/proyek tertentu, tesis maupun desertasi.

Kesalahan penulisan yang terjadi pada data tersebut yaitu penulisan kata baku pada kata desertasi. Penulisan kata tersebut melanggar PUEBI. Penulisan yang tepat yaitu Disertasi.

12) Mentaati

Dalam buku panduan perpustakaan IAIN Surakarta halaman 44 tertulis kalimat sebagai berikut:

Bersedia mentaati peraturan Perpustakaan IAIN Surakarta

Data kesalahan dalam kalimat di atas terdapat pada penulisan kata baku yakni kata mentaati. Kata tersebut mendapat imbuhan fonem [n] sehingga hal itu enyalahahi aturan penulisan kata baku dan melanggar kaidah dalam $K B B I$. Penulisan yang tepat yaitu menaati.

13) Seijin

Dalam buku panduan perpustakaan IAIN Surakarta halaman 44 tertulis kalimat sebagai berikut:

Membawa keluar koleksi perpustakaan tanpa seijin petugas

Penulisan kata seijin melanggar kaidah dalam PUEBI khususnya penulisan kata baku. Adapun penulisan yang tepat yaitu seizin.

14) Pasca sarjana

Dalam buku panduan perpustakaan IAIN Surakarta halaman 45 tertulis kalimat sebagai berikut:

5 judul, 5 eksemplar bagi mahasiswa pasca sarjana

Kata pasca sarjana merupakan kata tidak baku karena melanggar kaidah dalam KBBI. Penulisan yang tepat yaitu pascasarjana. Selain itu, terdapat kesalahan penulisan bilangan, yaitu bilangan yang terdapat di awal kalimat seharusnya ditulis dengan menggynakan huruf. 
Penulisan yang tepat, yaitu Lima judul, 5 eksemplar bagi mahasiswa pascasarjana.

15) Difotocopy

Dalam buku panduan perpustakaan IAIN Surakarta halaman 39 tertulis kalimat sebagai berikut:

Koleksi referensi hanya dapat dibaca di tempat atau difotocopy

Kesalahan yang terdapat pada kata yang dicetak miring tersebut termasuk dalam kesalahan penulisan kata baku. Karena kata fotocopy merupakan kata asing, maka dari itu penulisan yang tepat ialah difotokopi.

16) Didownload

Dalam buku panduan perpustakaan IAIN Surakarta halaman 28 tertulis kalimat sebagai berikut:

Setelah didownload akan muncul tampilan utama mLibsys IAIN Surakarta....

Kata yang dicetak miring dalam kalimat di atas menunjukkan adanya kesalahan dalam bidang penulisan kata baku. Kata download dalam istilah bahasa Indonesia, yaitu unduh. Maka pembenaran dari kata tersebut, yaitu diunduh.

17) Memfotocopy dan fotocopy

Dalam buku panduan perpustakaan IAIN Surakarta halaman 39 tertulis kalimat sebagai berikut:

Untuk koleksi sirkulasi anda boleh memfotocopy sendiri koleksi yang anda inginkan langsung di layanan fotocopy

Pada data di atas terdapat kesalahan penulisan kata baku, yaitu pada kata memfotocopy. Kata fotocopy merupakan kata asing dan kata tersebut telah diserap dalam istilah bahasa Indonesia yaitu fotokopi. Jadi, pada penulisannya jika memakai istilah bahasa Indonesia, yaitu memfotokopi.

18) Fotocopy

Dalam buku panduan perpustakaan IAIN Surakarta halaman 45 tertulis kalimat sebagai berikut:

Fotocopy koleksi referensi, tandon, serial dan skripsi, dapat dilakukan oleh pemustaka dengan melapor petugas di lantai 2 dan dibawa ke layanan fotocopy

Penulisan kata fotocopy pada kalimat di atas, menunjukkan adanya kesalahan berbahasa dalam penulisan kata baku. Kata tersebut merupakan kata asing dan sudah diserap dalam bahasa Indonesia, maka penulisan yang tepat ialah fotokopi. 
c. Kesalahan Penulisan Huruf Miring

19) Thesis

Dalam buku panduan perpustakaan IAIN Surakarta halaman 23, 24 dan 26 tertulis kalimat sebagai berikut:

Nomor klasifikasi. Untuk koleksi Skripsi/Thesis (halaman 23)

Untuk mencari repositori, thesis, skripsi dan koleksi digital (halaman 24)

Untuk mencari thesis terbaru silakan kunjungi.... (halaman 26)

Kata thesis pada data di atas menunjukkan kesalahan kata asing yang biasa digunakan masyarakat Indonesia. Penulisan yang tepat yaitu dicetak miring. Jika tidak dicetak miring, sebaiknya penggunaan kata tersebut diganti menggunakan istilah bahasa Indonesia, yaitu tesis.

20) Plagiarism

Dalam buku panduan perpustakaan IAIN Surakarta halaman 35 tertulis kalimat sebagai berikut:

...termasuk memriksa tulisan mahasiswa dari kemungkinan plagiarism

Kata plagiarism merupakan kata yang berasal dari istilah asing. Penulisan yang tepat ialah dicetak miring. Kata tersebut diserap dalam bahasa Indonesia menjadi plagiarisme. Maka, jika penulisannya menggunakan istilah bahasa Indonesia, penulisan yang tepat yaitu plagiarisme.

21) Locker

Dalam buku panduan perpustakaan IAIN Surakarta halaman 27 tertulis kalimat sebagai berikut:

Mintalah kunci locker

Kata locker pada kalimat di atas menunjukkan kesalahan berbahasa dalam penulisan huruf miring. Kata tersebut berasal dari istilah asing. Penulisan yang tepat yaitu dicetak miring. Kata tersebut juga telah diserap dalam bahasa Indonesia. Jadi, apabila digunakan dalam istilah bahasa Indonesia, penulisannya yang tepat yaitu loker.

\section{Kesalahan Kata dalam Bidang Ejaan}

a. Kesalahan Tanda Baca

22) Senin - Jumat

Dalam buku panduan perpustakaan IAIN Surakarta halaman 9 tertulis kalimat sebagai berikut:

Jam Buka Layanan: 5 (lima) hari.

Senin - Jumat: Pukul $07.00-17.30$

Sabtu $\quad$ : Pukul $07.00-10.00$

Data di atas menunjukkan kesalahan ejaan berupa tanda hubung (-) yang seharusnya tidak terpisah antara dua kata. Dalam kaidah kebahasaan yang sesuai dengan dalam Kamus Besar Bahasa Indonesia daring $\mathrm{V}$ penggunaan tanda baca hubung (-) harus melekat pada dua kata yang saling berhubungan. 
23) Di perpustakaan

Dalam buku panduan perpustakaan IAIN Surakarta halaman 17 tertulis kalimat sebagai berikut:

Tersedia meja baca dan kursi yang dapat dipergunakan untuk pemustaka membaca atau belajar di perpustakaan

Data di atas menunjukkan kesalahan adanya sebuah kalimat yang tidak terdapat tanda titik (.) pada akhir kalimat. Dalam kaidah kebahasaan yang sesuai dengan dalam Kamus Besar Bahasa Indonesia daring V penggunaan tanda baca titik (.) harus ada dalam setiap kata di akhir kalimat sebagai penanda satu kalimat.

b. Kesalahan Penulisan Kata Asing

24) Display

Dalam buku panduan perpustakaan IAIN Surakarta halaman 17 tertulis kalimat sebagai berikut:

Disediakan display koran untuk dibaca pengunjung perpustakaan dan di teras ini sebagai tempat pelaksanaan pameran buku perpustakaan.

Data di atas menunjukkan kesalahan pada kata "display" yang tidak tertulis miring. Dalam kaidah kebahasaan yang sesuai dengan dalam Kamus Besar Bahasa Indonesia daring V kata asing yang tertulis harus dalam posisi miring sebagai penanda bahwa kata tersebut bukan merupakan kata dari Bahasa Indonesia.

25) Lobby

Dalam buku panduan perpustakaan IAIN Surakarta halaman 17 tertulis kalimat sebagai berikut:

Lobby Perpustakaan

Data di atas menunjukkan kesalahan pada kata "Lobby" yang tidak tertulis miring. Dalam kaidah kebahasaan yang sesuai dengan dalam Kamus Besar Bahasa Indonesia daring V kata asing yang tertulis harus dalam posisi miring sebagai penanda bahwa kata tersebut bukan merupakan kata dari Bahasa Indonesia.

26) Cybernet

Dalam buku panduan perpustakaan IAIN Surakarta halaman 17 tertulis kalimat sebagai berikut:

Ruang Cybernet

Data di atas menunjukkan kesalahan pada kata "Cybernet" yang tidak tertulis miring. Dalam kaidah kebahasaan yang sesuai dengan dalam Kamus Besar Bahasa Indonesia daring V kata asing yang tertulis harus dalam posisi miring sebagai penanda bahwa kata tersebut bukan merupakan kata dari Bahasa Indonesia. 
27) Copy

Dalam buku panduan perpustakaan IAIN Surakarta halaman 19 tertulis kalimat sebagai berikut:

Semua koleksi copy 1 dari buku-buku sirkulasi.

Data di atas menunjukkan kesalahan pada kata "copy" yang tidak tertulis miring. Dalam kaidah kebahasaan yang sesuai dengan dalam Kamus Besar Bahasa Indonesia daring V kata asing yang tertulis harus dalam posisi miring sebagai penanda bahwa kata tersebut bukan merupakan kata dari Bahasa Indonesia.

28) Dewey

Dalam buku panduan perpustakaan IAIN Surakarta halaman 19 tertulis kalimat sebagai berikut:

Dewey demical clasification) versi umum dan Islam.

Data di atas menunjukkan kesalahan pada kata "dewey" yang tidak tertulis miring. Dalam kaidah kebahasaan yang sesuai dengan dalam Kamus Besar Bahasa Indonesia daring V kata asing yang tertulis harus dalam posisi miring sebagai penanda bahwa kata tersebut bukan merupakan kata dari Bahasa Indonesia.

29) Password

Dalam buku panduan perpustakaan IAIN Surakarta halaman 31 tertulis kalimat sebagai berikut:

7. Ganti Password.

Data di atas menunjukkan kesalahan pada kata "password" yang tidak tertulis miring. Dalam kaidah kebahasaan yang sesuai dengan dalam Kamus Besar Bahasa Indonesia daring V kata asing yang tertulis harus dalam posisi miring sebagai penanda bahwa kata tersebut bukan merupakan kata dari Bahasa Indonesia.

30) Username

Dalam buku panduan perpustakaan IAIN Surakarta halaman 31 tertulis kalimat sebagai berikut:

Maka jika username benar, maka akan muncul menu berikut ini:

Data di atas menunjukkan kesalahan pada kata "username" yang tidak tertulis miring. Dalam kaidah kebahasaan yang sesuai dengan dalam Kamus Besar Bahasa Indonesia daring V kata asing yang tertulis harus dalam posisi miring sebagai penanda bahwa kata tersebut bukan merupakan kata dari Bahasa Indonesia.

31) Locker

Dalam buku panduan perpustakaan IAIN Surakarta halaman 37 tertulis kalimat sebagai berikut:

Mintalah locker.

Data di atas menunjukkan kesalahan pada kata "Locker" yang tidak tertulis miring. Dalam kaidah kebahasaan yang sesuai dengan dalam 
Kamus Besar Bahasa Indonesia daring V kata asing yang tertulis harus dalam posisi miring sebagai penanda bahwa kata tersebut bukan merupakan kata dari Bahasa Indonesia.

\section{SIMPULAN}

Bahasa merupakan alat komunikasi yang digunakan untuk menangkap maksud pesan yang dituturkan oleh penutur. Bahasa Indonesia memiliki fungsi sebagai alat komunikasi utama bagi masyarakat Indonesia. Kesalahan berbahasa adalah suatu penggunan bahasa yang menyimpang dari kaidah bahasa Indonesia, baik lisan maupun tulis. Adapun analisis kesalahan berbahasa adalah suatu kegiatan yang mengkritik, memperbaiki, dan mengumpulkan suatu data kesalahan berbahasa dan mengklasifikasikannya sesuai bidangnya.

Dalam penelitian ini akan membahas lebih dalam mengenai kesalahan berbahasa dalam bentuk tulisan pada bagian diksi. Diksi dapat dimaknai sebagai bagian dari pengambilan kata oleh seorang penulis yang bertujuan untuk menyusun kalimat yang tepat. Buku panduan bisa disebut juga buku petunjuk, yaitu memuat tata cara mengenai suatu hal dalam melakukan sesuatu pekerjaan atau aktivitas tertentu. Buku panduan merupakan sebuat buku yang berisi tentang ketentuan-ketentuan dalam menjalankan perintah suatu kegiatan.

Berdasarkan hasil penelitian di atas, dapat disimpulkan bahwa di dalam buku panduan perpustakaan UPT Pusat Perpustakaan IAIN Surakarta Edisi 2018/2019 terdapat 32 data kesalahan dalam bidang diksi yang terdiri dari 3 data kesalahan penulisan kata depan 17 data kesalahan penulisan kata baku dan 5 data penulisan huruf miring. Dalam buku panduan perpustakaan UPT Pusat Perpustakaan IAIN Surakarta Edisi 2018/2019 terdapat 10 data kesalahan dalam bidang ejaan yang terdiri dari 2 data kesalahan tanda baca dan 8 kesalahan penggunaan kata asing.

\section{DAFTAR PUSTAKA}

Efrilla, D., Sari, A. W., \& Rahmi, A. (2017). Analisis Kesalahan Penggunaan Ejaan dan Diksi dalam Berita Surat Kabar Posmetro Padang. Di unduh dari http://jim.stkaip-pgrisumbar.ac.id

Hadijah, N. (2018). Analisis kesalahan ejaan dan diksi pada karangan teks deskripsi siswa kelas VII/B SMP Negeri 2 Gunungsari (Skripsi S1, Universitas Mataram, Lombok, Indonesia). Diunduh dari http://eprints.unram.ac.id.

Hidayatullah, A. (2018). Analisis kesalahan diksi pada karangan siswa kelas IX SMP Islam Daar El-Arqam Tangerang. El-Banar: Jurnal Pendidikan dan Pengajaran, 01, 41-50.

Johan, G. M. (2018). Analisis kesalahan berbahasa indonesia dalam proses diskusi siswa sekolah dasar. Jurnal Pendidikan Bahasa Dan Sastra, 18(June 2017), 136-149. https://doi.org/10.17509/bs

Moleong, L. J. (2014). Metode Penelitian Kulitatif. Bandung, Indonesia: Rosdakarya.

Nurwicaksono, B. D., \& Amelia, D. (2014). Analisis kesalahan berbahasa indonesia pada teks ilmiah mahasiswa. AKSIS, 152(March), 73-75.

Sugiyono. (2018). Metode Penelitian Pendidikan: Pendekatan Kualitatif, Kuantitatif dan R\&D. Bandung, Indonesia: Alfabeta.

Sumartono, R. S. (2014). Perbandingan penggunaan bahasa dalam kemampuan mengarang pada siswa kelas V SD Muhammadiyah 1 Waru dan SD Islam Al-Azhar 11 Surabaya. Skriptorium, 2(2).

Supriani, R., \& Siregar, I. R. (2012). Penelitian analisis kesalahan berbahasa. Jurnal Edukasi Kultura, 67-76. Diunduh dari http://jurnal.unimed.ac.id. 